\title{
The multiple facets of opioid receptor function: implications for addiction
}

\author{
Pierre-Eric Lutz ${ }^{1}$ and Brigitte L. Kieffer ${ }^{2}$ \\ ${ }^{1}$ McGill Group for Suicide Studies, Douglas Mental Health University Institute, McGill University, \\ Montreal, QC, Canada. \\ ${ }^{2}$ Institut de Génétique et de Biologie Moléculaire et Cellulaire, Centre National de Recherche \\ Scientifique/Institut National de la Santé et de la Recherche Médicale/Université de Strasbourg, \\ Illkirch-Graffenstaden, France.
}

\begin{abstract}
Addiction is characterized by altered reward processing, disrupted emotional responses and poor decision-making. Beyond a central role in drug reward, increasing evidence indicate that opioid receptors are more generally involved in all these processes. Recent studies establish the mu opioid receptor as a main player in social reward, which attracts increasing attention in psychiatric research. There is growing interest in blocking the kappa opioid receptor to prevent relapse, and alleviate the negative affect of withdrawal. The delta opioid receptor emerges as a potent mood enhancer, whose involvement in addiction is less clear. All three opioid receptors are likely implicated in addiction-depression comorbidity, and understanding of their roles in cognitive deficits associated to drug abuse is only beginning.
\end{abstract}

\section{Introduction}

Addiction stems from the progressive adaptation of the brain to repeated exposure to drugs of abuse. This complex brain disorder typically develops from an initiation phase, when the drug produces pleasurable, rewarding effects and is consumed recreationally. As the drug is used repeatedly, control of drug intake may be lost, leading to compulsive drug seeking and consumption. The addicted individual has entered a three-stage cycle, which involves binge/ intoxication episodes followed by withdrawal and a negative emotional state that in turn leads to a craving/preoccupation step to seek the drug, back to the intoxication step (Figure 1). Neural circuits contributing to this vicious cycle have been extensively studied, and reviewed recently [1]. Less studied is the neurobiology of protracted abstinence, which involves the development of a negative mood that strongly limits full recovery from a history of drug abuse.

The opioid system, including the mu (MOR), delta (DOR) and kappa (KOR) opioid receptors interacting with a large family of endogenous opioid peptides, is broadly distributed along the neurocircuitry of addiction. In this review we will focus on a selection of recently studied opioid receptor roles in addiction, and more generally psychiatric

\footnotetext{
(C) 2013 Elsevier Ltd. All rights reserved.

Corresponding author: Kieffer B.L. (briki@igbmc.fr).
}

Publisher's Disclaimer: This is a PDF file of an unedited manuscript that has been accepted for publication. As a service to our customers we are providing this early version of the manuscript. The manuscript will undergo copyediting, typesetting, and review of the resulting proof before it is published in its final citable form. Please note that during the production process errors may be discovered which could affect the content, and all legal disclaimers that apply to the journal pertain. 
research. A picture emerges where opioid receptors not only regulate drug reward, but also broadly contribute to emotional and cognitive processes whose dysfunction favors the development of addictive behaviors.

\section{Mu opioid receptor and reward: the social dimension}

The MOR is essential to mediate rewarding properties of opiates (morphine, heroin), as well as non-opioid drugs of abuse and natural stimuli [2,3] (Figure 1). Among these, social behaviors, which are recognized as intrinsically rewarding [4] and represent a major determinant of emotional well-being in humans [5], involve this receptor. In humans, neural sensitivity to social rejection [6] and social hedonic capacity [7] show significant association with a common variant of the MOR gene (A118G), although the functional significance of this polymorphism remains debated [8] and may implicate genetic-epigenetic interactions [9]. Recent animal research supports a key role for MOR in social attachment and anhedonia in mice [10], as well as affiliative behaviors in prairie voles [11].

Social anhedonia is raising increasing interest in drug abuse research [12]. As addiction develops, hedonic homeostasis is compromised and reward processes gradually shift, leading to increased motivation for drugs of abuse at the expense of naturally rewarding stimuli [13]. Social dysfunction and isolation are frequently encountered in addicted individuals and used as diagnostic criteria. A growing body of evidence suggest a possible overlap in the neural circuitry underlying "social pain" and physical pain, which are both modulated by opiates, and MOR activity may well be at the center of the intriguing relationship between these two unpleasant experiences [14]. Future experiments will likely substantiate this hypothesis.

\section{Mu opioid receptor and social reward along life: implications for addiction?}

Evidence is accumulating that reward processes are highly dynamic during ontogeny, particularly in the area of social behaviors, and MOR likely contributes to these processes all along life. Maternal attachment was reduced in MOR gene knockout (KO) pups [15], stressing a very early role of MOR in parent-infant affiliative behavior. Consistently, MOR gene variants correlated with the quality of parental attachment in infant primates $(\mathrm{C} 77 \mathrm{G}$, [16]) and humans (A118G, [17]). Recent studies also suggest that MOR-mediated responses vary with age, particularly during adolescence as social behaviors become particularly important [18]. Social play, acting as a natural reinforcer in adolescent rats and mice, induced a conditioned place preference (CPP) and was potentiated by activation of MORs in the nucleus accumbens (NAc) [19] (Figure 2). Further, MOR stimulation by morphine substituted for social peer exploration (with different sensitivity across inbred strains) in adolescent but not adult mice [20]. Also, heroin self-administration and seeking [21], as well as emotional responses to opioid withdrawal [22, 23] differed between adolescent and adult rodents. Together, the latter studies show increased reinforcing effects of mu opiates and decreased aversive effects of opioid withdrawal in adolescent animals, which is consistent with the notion that susceptibility to initiate addictive behaviors is higher during this life period [24].

Researchers now face the difficult task of clarifying the molecular basis of dynamic MOR function along development, and the significance of age-dependent MOR-mediated reward in the overall lifetime risk of addiction. 


\section{Kappa opioid receptor and aversive states: stress and addiction}

In addiction research, dynorphin/KOR activity is definitely considered a major anti-reward system, producing dysphoric effects and antagonizing rewarding effects of drugs of abuse and social stimuli [25]. Accordingly, KOR activation in the NAc decreased social play in adolescent rats [19], and mediated selective aggression towards novel conspecifics in prairie voles, thereby supporting pair bond maintenance [26]. In addition, it is well established that social or physical stressors, as well as prolonged exposure to drugs of abuse increase activity of the dynorphin/KOR system, notably through corticotropin-releasing factor (CRF) signaling [27, 28]. Enhanced tonic KOR function, in turn, may represent one mechanism underlying the pro-addictive effect of stress, notably by promoting relapse [27]. More generally, stress-induced KOR activation has strong pro-depressant effects, and KOR blockade is considered a promising strategy to treat depressive disorders [29].

Most recent studies have addressed brain sites and neurotransmitters involved in KORmediated aversive states and modulation of drug reward, and there is strong evidence that serotonergic signaling is involved. Local infusion of the KOR antagonist nor-BNI in the dorsal raphe nucleus (DRN) blocked U50,488 CPA, as well as social stress-induced reinstatement of cocaine CPP [30]. Further genetic approaches established a key role for KORs expressed by DRN serotonergic neurons projecting onto the NAc, and showed that this particular KOR population produces aversion and potentiates cocaine reward via $\mathrm{p} 38 \mathrm{a}$ MAP kinase signaling [31, 32]. Beyond cocaine and the DRN, stress-induced activation of KOR in the amygdala potentiated nicotine CPP [33], and future studies will determine whether stress/KOR-mediated effects on drug reward extend to most drugs of abuse.

In conclusion, an endogenous dynorphin/KOR tone emerges under stressors, which typically intensify while addiction develops, contributing to negative emotional states of acute withdrawal and protracted abstinence (see Figure 1 and section 5 below). A recent observation supporting this view is that pharmacological KOR blockade had no effect on alcohol self-administration in naive rats, but reduced this behavior in rats previously made dependent on alcohol [34].

\section{Delta opioid receptor and emotions: potential impact on addiction}

The exact role of DOR in brain function has emerged only recently, with the availability of genetic tools and highly selective drugs [35]. The importance of DOR activity to reduce levels of anxiety and attenuate depressive-like states is now well established [35] (Figure 1).

However, DOR implication in drug reward and addictive behaviors is the subject of debate [36]. KO mice studies indicate that DOR contributes to nicotine, but not morphine, D9 tetrahydrocannabinol (THC) or 3,4-methylenedioxy-N-methylamphetamine (MDMA) CPP. Further morphine self-administration was maintained in DOR mutant mice, suggesting altogether that reward processes are not, or only weakly regulated by DOR (reviewed in [35]). Importantly, DOR KO mice drunk more alcohol while reducing their innate anxiety levels [37]; activation of DORs in the ventral tegmental area diminished alcohol consumption [38], and the delta agonist TAN-67 reduced levels of anxiety and depressivelike behaviors in alcohol- and cocaine-withdrawn mice (see [35]). These data together point at a role for DOR in emotional comorbidity associated with addiction (see section 5 below). Future investigations will determine whether this observation generalizes to other drugs of abuse.

Finally, a recent analysis of DOR KO mice suggests that DOR activity facilitates association of morphine effects with the context, but not other cues [39, 40]. In hippocampal interneurons, the drug-context association engages opioid peptide-mediated activation of the 
DOR [41], whose implication in context-dependent memory processes, and potentially context-induced relapse, requires further investigations.

\section{The opioid system in emotional comorbidities of addiction}

Addiction-depression comorbidity is highly prevalent in humans [42]. Animal research indicates that antidepressant medication reverses anhedonia in rats undergoing spontaneous nicotine or amphetamine withdrawal, suggesting shared biology between depression and depressive symptoms of acute drug withdrawal (see [43]). Recently, a mouse study reported the development of emotional deficits during protracted abstinence to morphine. Social withdrawal and despair-like behavior increased along a 4-week abstinence period [44]. Morphine-abstinent mice showed durable modifications of the serotonergic system, and treatment with fluoxetine (a specific serotonin reuptake inhibitor) during abstinence prevented the development of emotional dysfunction $[44,45]$.

Protracted abstinence has been little investigated in animal research, and further studies will be important to investigate the dynamics of molecular and circuit adaptations involved in this key aspect of addiction (Figure 1). MOR, DOR and KOR are distinct, yet central players for both reward processing and emotional control, and likely contribute to the negative emotional states of protracted abstinence (Figure 1) [42, 46]. The analysis of how and where opioid receptors modulate monoaminergic transmission along a history of drug abuse, for example, is only beginning (serotonin and KOR, see section 3 ).

\section{The opioid system, decision-making and addiction}

Increasing evidence shows neurocognitive deficits in the development of addictive behavior. Recreational drug use initially engages both goal-directed and impulsive actions [47], and these gradually evolve while addiction develops. Executive controls decline so that behaviors shift from goal-directed to habitual behaviors and drug consumption becomes compulsive. The implication of opioid receptors in poor decision-making of addicted individuals has been substantiated recently.

Goal-directed behavior is controlled by hedonic and incentive properties of rewarding stimuli. Naloxone blockade experiments showed that endogenous opioids are required for the processing of both properties of natural rewards, and that these controls occur in distinct brain regions (ventral pallidum or the shell of the NAc for the former, baso-lateral amygdala, BLA, for the latter) [48]. Further, receptor blockage using specific antagonists indicated that MOR, but not DOR or KOR, controls incentive learning in the BLA [49] (Figure 2).

Decision-making, i.e choosing between several goal-directed behaviors, involves comparing both (i) reward value of actions goals and (ii) likelihood of reward when performing these actions. A recent study in the mouse showed that MOR in the NAc core is essential for the first aspect, while DOR in the NAc shell is necessary to encode the second [50]. In humans, naltrexone impaired decision-making processes, in both alcoholics and healthy controls [51], but the precise opioid receptor mechanism remains to be determined.

Regarding inhibitory controls, a mouse genetic study showed that MOR and DOR oppositely regulate motor impulsivity, and suggested that MOR reduces while DOR increases inhibition [52]. Pharmacological studies in rats also supported a role for MOR in several measures of impulsivity [53] and for DOR in response inhibition [54]. In human, PET imaging revealed that high MOR activity (both basal and stress-induced) correlates with high impulsiveness [55], in accordance with animal data. At present, no study has addressed MOR gene polymorphisms [8] in relation to these behaviors. 
Therefore, both MOR and DOR regulate normal goal-directed processes and impulsivity. These activities could contribute to both addiction vulnerability and the development of pathological drug consumption. MOR, but not DOR or KOR, blockade in the NAc shell attenuated deleterious effects of amphetamine on inhibitory controls [56], and repeated MOR activation progressively increased levels of impulsivity during prolonged heroin selfadministration [57]. Importantly, a recent study established a causal relationship between MOR function and the emergence of a compulsive-like behavior. In this study wild type mice developed compulsive-like morphine oral self-administration, but this was not observed in knock-in animals expressing a mutant MOR designed to desensitize and internalize in response to morphine [58].

\section{Acknowledgments}

We would like to thank Sandra Bour for her help with figures preparation. This work was supported by the CNRS, INSERM and Université de Strasbourg. We also thank the Mouse Clinical Institute (ICS, Illkirch France), the European Union (Grant No.GENADDICT/FP6 005166), the Fondation pour la Recherche Médicale (P.E.L.), the Fondation Fyssen (P.E.L.), and the National Institutes of Health (National Institute of Drug Addiction, grant \#05010 and National Institute on Alcohol Abuse and Alcoholism, grant \#16658) for financial support.

\section{References}

1. Koob GF, Volkow ND. Neurocircuitry of addiction. Neuropsychopharmacology. 2010; 35:217-238. [PubMed: 19710631]

2. Contet C, Kieffer BL, Befort K. Mu opioid receptor: a gateway to drug addiction. Curr Opin Neurobiol. 2004; 14:370-378. [PubMed: 15194118]

3. Le Merrer J, Becker JA, Befort K, Kieffer BL. Reward processing by the opioid system in the brain. Physiol Rev. 2009; 89:1379-1412. [PubMed: 19789384]

4. Trezza V, Baarendse PJ, Vanderschuren LJ. The pleasures of play: pharmacological insights into social reward mechanisms. Trends Pharmacol Sci. 2010; 31:463-469. [PubMed: 20684996]

5. Meyer-Lindenberg A, Tost H. Neural mechanisms of social risk for psychiatric disorders. Nat Neurosci. 2012; 15:663-668. [PubMed: 22504349]

6. Way BM, Taylor SE, Eisenberger NI. Variation in the mu-opioid receptor gene (OPRM1) is associated with dispositional and neural sensitivity to social rejection. Proc Natl Acad Sci U S A. 2009; 106:15079-15084. [PubMed: 19706472] . ** Neural regions encoding the affective component of pain are also activated by social stressors, and both are alleviated by morphine treatment. In particular, this paper reveals that reactivity to social rejection, and fMRI activation in the anterior cingulate cortex and anterior insula, are increased in humans carrying the minor allele $118 \mathrm{G}$ of the mu opioid receptor gene.

7. Troisi A, Frazzetto G, Carola V, Di Lorenzo G, Coviello M, D'Amato FR, Moles A, Siracusano A, Gross C. Social hedonic capacity is associated with the A118G polymorphism of the mu-opioid receptor gene (OPRM1) in adult healthy volunteers and psychiatric patients. Soc Neurosci. 2011; 6:88-97. [PubMed: 20486014]

8. Mague SD, Blendy JA. OPRM1 SNP (A118G): involvement in disease development, treatment response, and animal models. Drug Alcohol Depend. 2010; 108:172-182. [PubMed: 20074870]

9. Oertel BG, Doehring A, Roskam B, Kettner M, Hackmann N, Ferreiros N, Schmidt PH, Lotsch J. Genetic-epigenetic interaction modulates mu-opioid receptor regulation. Hum Mol Genet. 2012; 21:4751-4760. [PubMed: 22875838] . * The human polymorphism A118G at the mu opioid receptor gene has been extensively studied in the contexts of addiction and mood disorders, with largely conflicting results. This paper indicates that in human post-mortem brains, the minor allele 118G, which introduces a new CpG site, associates with increased DNA methylation, that may prevent the up-regulation of the mu opioid receptor expression observed in chronic opiate abusers.

10. Cinque C, Pondiki S, Oddi D, Di Certo MG, Marinelli S, Troisi A, Moles A, D'Amato FR. Modeling socially anhedonic syndromes: genetic and pharmacological manipulation of opioid neurotransmission in mice. Transl Psychiatry. 2012; 2:e155. [PubMed: 22929597] 
11. Burkett JP, Spiegel LL, Inoue K, Murphy AZ, Young LJ. Activation of mu-opioid receptors in the dorsal striatum is necessary for adult social attachment in monogamous prairie voles. Neuropsychopharmacology. 2011; 36:2200-2210. [PubMed: 21734650]

12. Volkow ND, Baler RD, Goldstein RZ. Addiction: pulling at the neural threads of social behaviors. Neuron. 2011; 69:599-602. [PubMed: 21338873]

13. Der-Avakian A, Markou A. The neurobiology of anhedonia and other reward-related deficits. Trends Neurosci. 2012; 35:68-77. [PubMed: 22177980]

14. Eisenberger NI. The pain of social disconnection: examining the shared neural underpinnings of physical and social pain. Nat Rev Neurosci. 2012; 13:421-434. [PubMed: 22551663]

15. Moles A, Kieffer BL, D'Amato FR. Deficit in attachment behavior in mice lacking the mu-opioid receptor gene. Science. 2004; 304:1983-1986. [PubMed: 15218152]

16. Barr CS, Schwandt ML, Lindell SG, Higley JD, Maestripieri D, Goldman D, Suomi SJ, Heilig M. Variation at the mu-opioid receptor gene (OPRM1) influences attachment behavior in infant primates. Proc Natl Acad Sci U S A. 2008; 105:5277-5281. [PubMed: 18378897]

17. Copeland WE, Sun H, Costello EJ, Angold A, Heilig MA, Barr CS. Child mu-opioid receptor gene variant influences parent-child relations. Neuropsychopharmacology. 2011; 36:1165-1170. [PubMed: 21326192]

18. Panksepp JB, Lahvis GP. Rodent empathy and affective neuroscience. Neurosci Biobehav Rev. 2011; 35:1864-1875. [PubMed: 21672550]

19. Trezza V, Damsteegt R, Achterberg EJ, Vanderschuren LJ. Nucleus Accumbens \{micro\}-Opioid Receptors Mediate Social Reward. J Neurosci. 2011; 31:6362-6370. [PubMed: 21525276] . * Social play is a highly rewarding stimulus in adolescent rats, that can be modulated by systemic exposure to opiates. Here, the authors show that activation in the nucleus accumbens of both mu and kappa, but not delta, opioid receptors bidirectionnaly regulate the expression of social play behaviors. In addition, blockade of mu opioid receptor in this brain region prevents social playinduced conditioned place preference.

20. Kennedy BC, Panksepp JB, Wong JC, Krause EJ, Lahvis GP. Age-dependent and strain-dependent influences of morphine on mouse social investigation behavior. Behav Pharmacol. 2011; 22:147159. [PubMed: 21358324]

21. Doherty JM, Frantz KJ. Heroin self-administration and reinstatement of heroin-seeking in adolescent vs. adult male rats. Psychopharmacology (Berl). 2011; 219:763-773. [PubMed: 21773722]

22. Hodgson SR, Hofford RS, Wellman PJ, Eitan S. Different affective response to opioid withdrawal in adolescent and adult mice. Life Sci. 2009; 84:52-60. [PubMed: 19032959]

23. Lutz PE, Reiss D, Ouagazzal AM, Kieffer BL. A history of chronic morphine exposure during adolescence increases despair-like behaviour and strain-dependently promotes sociability in abstinent adult mice. Behavioural brain research. 2013

24. Schramm-Sapyta NL, Walker QD, Caster JM, Levin ED, Kuhn CM. Are adolescents more vulnerable to drug addiction than adults? Evidence from animal models. Psychopharmacology (Berl). 2009; 206:1-21. [PubMed: 19547960]

25. Wee S, Koob GF. The role of the dynorphin-kappa opioid system in the reinforcing effects of drugs of abuse. Psychopharmacology (Berl). 2010; 210:121-135. [PubMed: 20352414]

26. Resendez SL, Kuhnmuench M, Krzywosinski T, Aragona BJ. kappa-Opioid Receptors within the Nucleus Accumbens Shell Mediate Pair Bond Maintenance. J Neurosci. 2012; 32:6771-6784. [PubMed: 22593047]

27. Bruchas MR, Land BB, Chavkin C. The dynorphin/kappa opioid system as a modulator of stressinduced and pro-addictive behaviors. Brain Res. 2010; 1314:44-55. [PubMed: 19716811]

28. Van't Veer A, Yano JM, Carroll FI, Cohen BM, Carlezon WA Jr. Corticotropin-Releasing Factor (CRF)-Induced Disruption of Attention in Rats Is Blocked by the kappa-Opioid Receptor Antagonist JDTic. Neuropsychopharmacology. 2012; 37:2809-2816. [PubMed: 22948977]

29. Knoll AT, Carlezon WA Jr. Dynorphin, stress, and depression. Brain Res. 2010; 1314:56-73. [PubMed: 19782055]

30. Land BB, Bruchas MR, Schattauer S, Giardino WJ, Aita M, Messinger D, Hnasko TS, Palmiter $\mathrm{RD}$, Chavkin C. Activation of the kappa opioid receptor in the dorsal raphe nucleus mediates the 
aversive effects of stress and reinstates drug seeking. Proc Natl Acad Sci U S A. 2009; 106:1916819173. [PubMed: 19864633]

31. Bruchas MR, Schindler AG, Shankar H, Messinger DI, Miyatake M, Land BB, Lemos JC, Hagan CE, Neumaier JF, Quintana A, et al. Selective p38alpha MAPK Deletion in Serotonergic Neurons Produces Stress Resilience in Models of Depression and Addiction. Neuron. 2011; 71:498-511. [PubMed: 21835346] . ** Acute social defeat is used to induce social avoidance and reinstate cocaine conditioned place preference. Using conditional gene knockout, the authors demonstrate that these effects of social stress depend on activation of the kappa opioid receptor and the downstream p38 a signaling pathway in serotonergic neurons of the dorsal raphe nucleus.

32. Schindler AG, Messinger DI, Smith JS, Shankar H, Gustin RM, Schattauer SS, Lemos JC, Chavkin NW, Hagan CE, Neumaier JF, et al. Stress Produces Aversion and Potentiates Cocaine Reward by Releasing Endogenous Dynorphins in the Ventral Striatum to Locally Stimulate Serotonin Reuptake. J Neurosci. 2012; 32:17582-17596. [PubMed: 23223282]

33. Smith JS, Schindler AG, Martinelli E, Gustin RM, Bruchas MR, Chavkin C. Stress-Induced Activation of the Dynorphin/kappa-Opioid Receptor System in the Amygdala Potentiates Nicotine Conditioned Place Preference. J Neurosci. 2012; 32:1488-1495. [PubMed: 22279233]

34. Walker BM, Zorrilla EP, Koob GF. Systemic kappa-opioid receptor antagonism by norbinaltorphimine reduces dependence-induced excessive alcohol self-administration in rats. Addict Biol. 2011; 16:116-119. [PubMed: 20579007]

35. Pradhan AA, Befort K, Nozaki C, Gaveriaux-Ruff C, Kieffer BL. The delta opioid receptor: an evolving target for the treatment of brain disorders. Trends Pharmacol Sci. 2011; 32:581-590. [PubMed: 21925742]

36. Shippenberg TS, LeFevour A, Chefer VI. Targeting endogenous muand delta-opioid receptor systems for the treatment of drug addiction. CNS Neurol Disord Drug Targets. 2008; 7:442-453. [PubMed: 19128202]

37. Roberts AJ, Gold LH, Polis I, McDonald JS, Filliol D, Kieffer BL, Koob GF. Increased ethanol self-administration in delta-opioid receptor knockout mice. Alcohol Clin Exp Res. 2001; 25:12491256. [PubMed: 11584142]

38. Margolis EB, Fields HL, Hjelmstad GO, Mitchell JM. Delta-opioid receptor expression in the ventral tegmental area protects against elevated alcohol consumption. The Journal of neuroscience : the official journal of the Society for Neuroscience. 2008; 28:12672-12681. [PubMed: 19036960]

39. Le Merrer J, Plaza-Zabala A, Del Boca C, Matifas A, Maldonado R, Kieffer BL. Deletion of the delta opioid receptor gene impairs place conditioning but preserves morphine reinforcement. Biol Psychiatry. 2011; 69:700-703. [PubMed: 21168121]

40. Le Merrer J, Faget L, Matifas A, Kieffer BL. Cues predicting drug or food reward restore morphine-induced place conditioning in mice lacking delta opioid receptors. Psychopharmacology (Berl). 2012; 223:99-106. [PubMed: 22526530]

41. Faget L, Erbs E, Le Merrer J, Scherrer G, Matifas A, Benturquia N, Noble F, Decossas M, Koch M, Kessler P, et al. In Vivo Visualization of Delta Opioid Receptors upon Physiological Activation Uncovers a Distinct Internalization Profile. J Neurosci. 2012; 32:7301-7310. [PubMed: 22623675] . * The authors study delta opioid receptor endocytosis in vivo, using a reporter knockin mouse for the receptor. Context-induced withdrawal triggers endogenous peptide release in the hippocampus, which in turn internalizes the receptor in an unusual pattern. This is the first demonstration that physiological and pharmacological activation of a $\mathrm{G}$ protein coupled receptor leads to distinct internalization fates.

42. Lutz PE, Kieffer BL. Opioid receptors: distinct roles in mood disorders. Trends Neurosci. 2012

43. Paterson NE, Markou A. Animal models and treatments for addiction and depression co-morbidity. Neurotox Res. 2007; 11:1-32. [PubMed: 17449445]

44. Goeldner C, Lutz PE, Darcq E, Halter T, Clesse D, Ouagazzal AM, Kieffer BL. Impaired emotional-like behavior and serotonergic function during protracted abstinence from chronic morphine. Biol Psychiatry. 2011; 69:236-244. [PubMed: 20947067] . * The authors show that following chronic morphine exposure, despair-like behavior and decreased social interactions progressively during extended abstinence. They also demonstrate that these deficits correlate with 
disrupted serotonin metabolism in the dorsal raphe nucleus, and are reversed by chronic fluoxetine treatment.

45. Lutz PE, Pradhan AA, Goeldner C, Kieffer BL. Sequential and opposing alterations of 5-HT(1A) receptor function during withdrawal from chronic morphine. Eur Neuropsychopharmacol. 2011; 21:835-840. [PubMed: 21402471]

46. Berrocoso E, Sanchez-Blazquez P, Garzon J, Mico JA. Opiates as antidepressants. Curr Pharm Des. 2009; 15:1612-1622. [PubMed: 19442177]

47. Robbins TW, Gillan CM, Smith DG, de Wit S, Ersche KD. Neurocognitive endophenotypes of impulsivity and compulsivity: towards dimensional psychiatry. Trends in cognitive sciences. 2012; 16:81-91. [PubMed: 22155014]

48. Wassum KM, Ostlund SB, Maidment NT, Balleine BW. Distinct opioid circuits determine the palatability and the desirability of rewarding events. Proc Natl Acad Sci U S A. 2009; 106:12512_ 12517. [PubMed: 19597155]

49. Wassum KM, Cely IC, Balleine BW, Maidment NT. \{micro\}-Opioid Receptor Activation in the Basolateral Amygdala Mediates the Learning of Increases But Not Decreases in the Incentive Value of a Food Reward. J Neurosci. 2011; 31:1591-1599. [PubMed: 21289167]

50. Laurent V, Leung B, Maidment N, Balleine BW. mu- and delta-opioid-related processes in the accumbens core and shell differentially mediate the influence of reward-guided and stimulusguided decisions on choice. J Neurosci. 2012; 32:1875-1883. [PubMed: 22302826]

51. Mitchell JM, Tavares VC, Fields HL, D'Esposito M, Boettiger CA. Endogenous opioid blockade and impulsive responding in alcoholics and healthy controls. Neuropsychopharmacology. 2007; 32:439-449. [PubMed: 17047667]

52. Olmstead MC, Ouagazzal AM, Kieffer BL. Mu and delta opioid receptors oppositely regulate motor impulsivity in the signaled nose poke task. PLoS One. 2009; 4:4410.

53. Pattij T, Schetters D, Janssen MC, Wiskerke J, Schoffelmeer AN. Acute effects of morphine on distinct forms of impulsive behavior in rats. Psychopharmacology (Berl). 2009; 205:489-502. [PubMed: 19436995]

54. Befort K, Mahoney MK, Chow C, Hayton SJ, Kieffer BL, Olmstead MC. Effects of delta opioid receptors activation on a response inhibition task in rats. Psychopharmacology (Berl). 2011; 214:967-976. [PubMed: 21181131]

55. Love TM, Stohler CS, Zubieta JK. Positron emission tomography measures of endogenous opioid neurotransmission and impulsiveness traits in humans. Arch Gen Psychiatry. 2009; 66:1124-1134. [PubMed: 19805703]

56. Wiskerke J, Schetters D, van Es IE, van Mourik Y, den Hollander BR, Schoffelmeer AN, Pattij T. mu-Opioid receptors in the nucleus accumbens shell region mediate the effects of amphetamine on inhibitory control but not impulsive choice. J Neurosci. 2011; 31:262-272. [PubMed: 21209211]

57. Schippers MC, Binnekade R, Schoffelmeer AN, Pattij T, De Vries TJ. Unidirectional relationship between heroin self-administration and impulsive decision-making in rats. Psychopharmacology (Berl). 2012; 219:443-452. [PubMed: 21887498]

58. Berger AC, Whistler JL. Morphine-induced mu opioid receptor trafficking enhances reward yet prevents compulsive drug use. EMBO Mol Med. 2011; 3:385-397. [PubMed: 21656686] . * Compulsive-like behaviors were previously demonstrated during prolonged cocaine intravenous self-administration in rat. Here, similar behaviors are shown for the first time in mice selfadministering morphine orally. Analysis of a mutant mouse line shows that compulsive behaviors are regulated by MOR trafficking.

59. Belin D, Mar AC, Dalley JW, Robbins TW, Everitt BJ. High impulsivity predicts the switch to compulsive cocaine-taking. Science. 2008; 320:1352-1355. [PubMed: 18535246]

60. Slowe SJ, Simonin F, Kieffer B, Kitchen I. Quantitative autoradiography of mu-,delta- and kappa1 opioid receptors in kappa-opioid receptor knockout mice. Brain Res. 1999; 818:335-345. [PubMed: 10082819]

61. Kitchen I, Slowe SJ, Matthes HW, Kieffer B. Quantitative autoradiographic mapping of mu-, deltaand kappa-opioid receptors in knockout mice lacking the mu-opioid receptor gene. Brain Res. 1997; 778:73-88. [PubMed: 9462879] 
62. Goody RJ, Oakley SM, Filliol D, Kieffer BL, Kitchen I. Quantitative autoradiographic mapping of opioid receptors in the brain of delta-opioid receptor gene knockout mice. Brain Res. 2002; 945:919. [PubMed: 12113946]

63. Schumann G, Loth E, Banaschewski T, Barbot A, Barker G, Buchel C, Conrod PJ, Dalley JW, Flor $\mathrm{H}$, Gallinat J, et al. The IMAGEN study: reinforcement-related behaviour in normal brain function and psychopathology. Mol Psychiatry. 2010; 15:1128-1139. [PubMed: 21102431] 


\section{Highlights}

- The mu opioid receptor is a main player in social and developmental rewards

- Blocking the kappa opioid receptor may prevent relapse and social aversion

- The delta opioid receptor is a mood enhancer, with a debated role in addiction

- All three receptors may regulate addiction-related mood and cognitive disorders 


\section{Perspectives}

Beyond a central role in drug reward, recent evidence now indicates that opioid receptors play key roles in the many facets of substance use (Figure 2). MOR is a main actor in brain processing of rewarding properties of social stimuli, an area of investigation attracting increasing attention in psychiatric research. Dissecting specific underlying neuronal circuits will be necessary to achieve an integrated view of brain mechanisms encoding the multiple forms of reward, and their adaptations during the course of addiction. KOR is now recognized as a key player in stress-induced addictive-like behaviors, and blocking KOR is a promising strategy to prevent relapse and alleviate negative affect in addiction. Also, all three opioid receptors appear as distinct, key players in emotional comorbidities of addiction. Finally, MOR and DOR are implicated in goal-directed actions and inhibitory controls. Improving our understanding of specific MOR, DOR and potentially KOR functions in compulsive behaviors associated with addiction will require the use of sophisticated recent animal models [59]. More generally, the development of translational studies is strongly needed to understand the specific function of each receptor, particularly DOR and KOR, in addicted patients. 

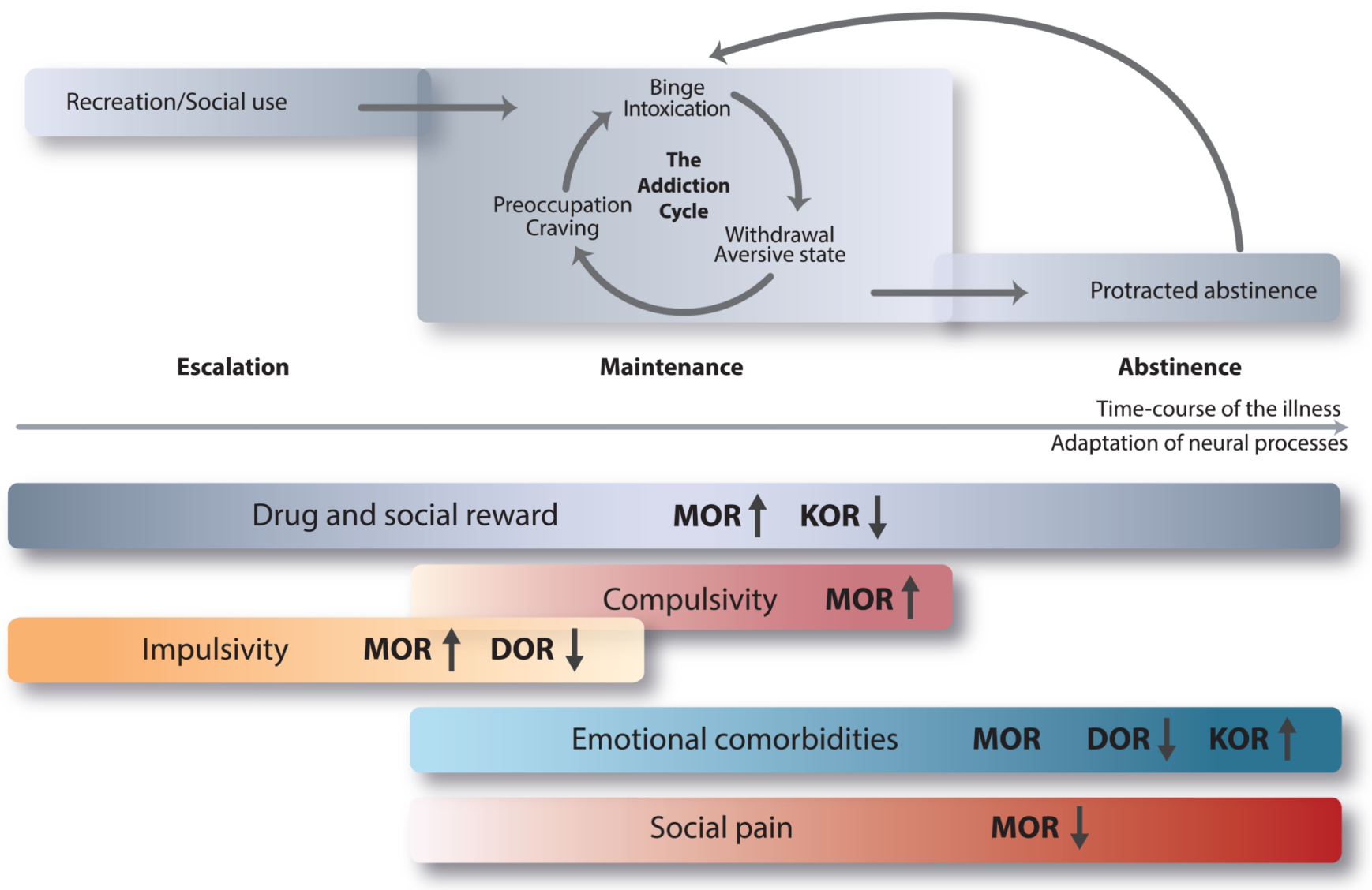

Figure 1. Opioid receptors are key players in most brain processes underlying addiction Top. In addicted individuals, recreational drug use switches to compulsive drug intake. The addiction cycle typically includes intoxication/withdrawal/craving episodes [1]. Exiting the vicious cycle requires strict maintenance of abstinence. Drug abstinence in former addicts is characterized by a negative affect, which strongly contributes to relapse [44]. Bottom. The mu and kappa opioid receptors (MOR and KOR) exert opposing control over drug and social reward, with MOR enhancing and KOR reducing reward processing. MOR and delta (DOR) opioid receptors oppositely regulate inhibitory controls, with MOR and DOR activities increasing and decreasing motor impulsivity, respectively. MOR-mediated reward and impulsivity likely contribute to initiate drug use. The three opioid receptors fulfill distinct roles in addiction-related emotional disorders, with pro- and antidepressant-like activity for KOR and DOR, respectively, and a complex role for MOR [42]. The MOR may also be a key player in brain pathways encoding social pain. Arrows indicate the effects of opioid receptors activities. 
(a)

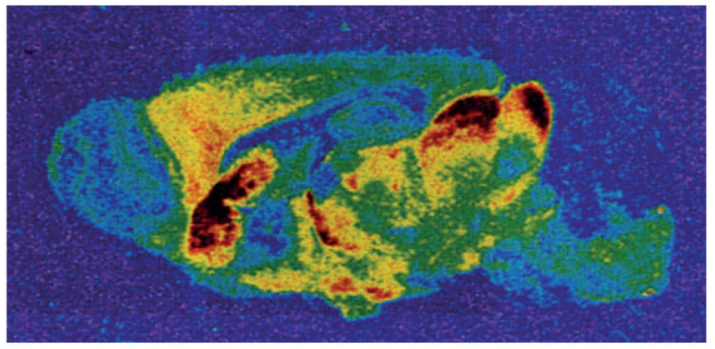

(b)

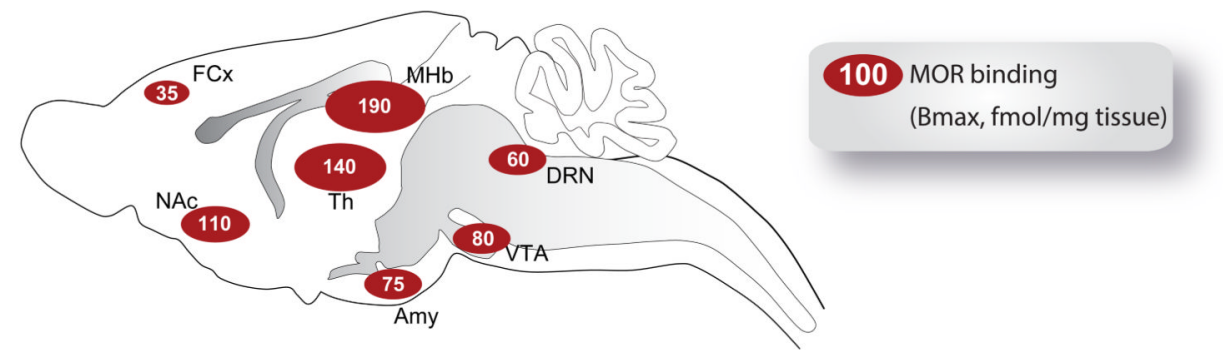

(c)

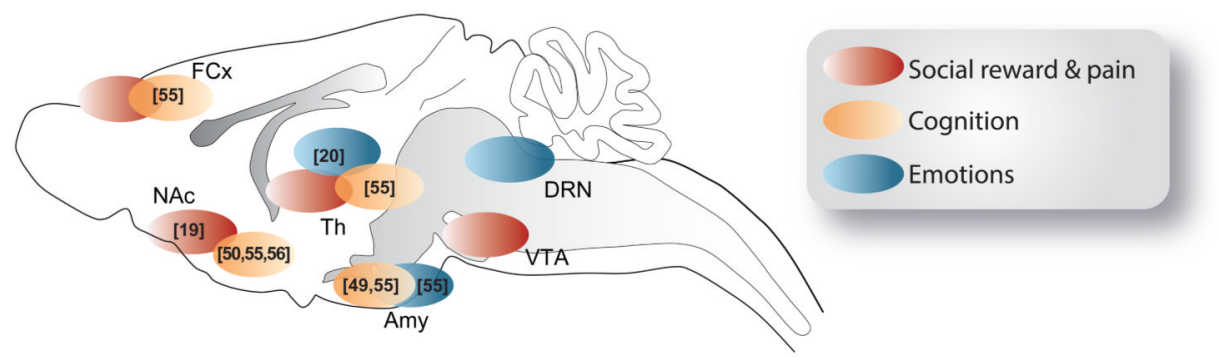

(d)

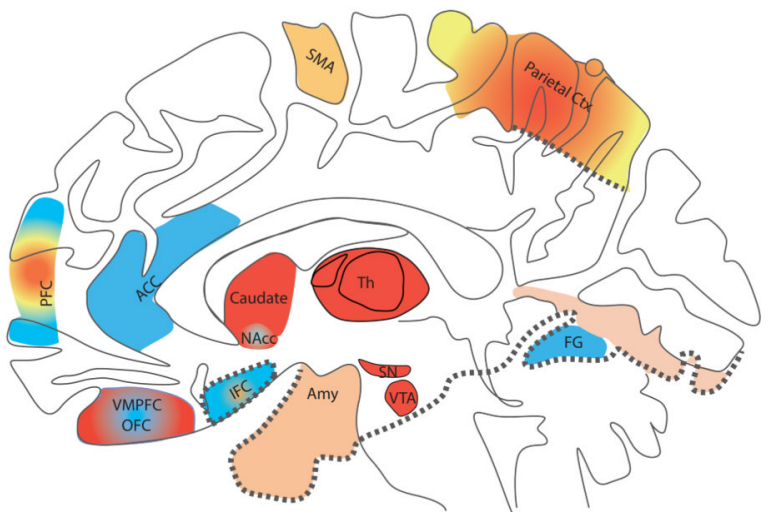

Social brain

Inhibitory control system

Reward system

Figure 2. The mu opioid receptor (MOR) controls a number of addiction-related neuronal processes throughout the brain

In rodents, the MOR is enriched in brain regions mediating: social reward and pain, cognition (impulsive behaviors and decision-making) and emotional responses. (a) Autoradiogram of a sagittal mouse brain section showing $\left[{ }^{3} \mathrm{H}\right]$-DAMGO MOR binding (Courtesy of Pr Ian Kitchen [60-62]), where highest densities are represented in dark red.

(b) Corresponding absolute values of $\left[{ }^{3} \mathrm{H}\right]$-DAMGO MOR binding in selected brain regions. (c) Addiction-related brain structures and neuronal functions for which a role of MOR is demonstrated (references between brackets, see also the main text) or suggested. MOR pools in the ventral tegmental area (VTA) and the frontal cortex (FCx) tightly control drug reward, 
and likely also regulate social reward. MORs in the dorsal raphe nucleus (DRN) and thalamus (Th) may modulate emotions and the affective dimension of social painful experiences, respectively. The potential relevance for addiction of MOR located in the medial habenula $(\mathrm{MHb})$ - the highest MOR expression site in the brain - remains currently unknown. (d) Although rodent and human brain functions cannot be matched exactly, studies of human addiction similarly focus on social reward and dysfunction, the disruption of executive functions and the development of emotional comorbidities (courtesy of $\operatorname{Pr}$ Gunter Schuman [63]). Abbreviations: ACC, anterior cingulate cortex; Amy, amygdala; BLA, basolateral amygdala; IFC, infralimbic cortex; NAc, nucleus accumbens; OFC, orbitofrontal cortex; PFC, prefrontal cortex; SN, substancia nigra; VMPFC, ventromedial prefrontal cortex. 